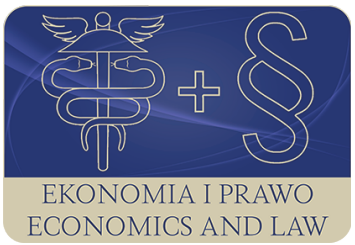

EKONOMIA I PRAWO. ECONOMICS AND LAW Volume 17, Issue 4, December 2018 p-ISSN 1898-2255, e-ISSN 2392-1625

www.economicsandlaw.pl

ORIGINAL ARTICLE received 02.01.2018; revised 18.05.2018; accepted 31.12.2018 Citation: Heller, J., \& Warżała, R. (2018). Is Poland in a middle income trap? A theoretical and empirical analysis. Ekonomia i Prawo. Ecomomics and Law, 17(4): 367-381. doi:10.12775/EiP.2018.027.

\title{
Is Poland in a middle income trap? A theoretical and empirical analysis
}

\author{
JANUSZ HELLER \\ corresponding author \\ University of Warmia and Mazuria in Olsztyn, Faculty of Economic Sciences, Department \\ of Macroeconomics, ul. M. Oczapowskiego 2, 10-719 Olsztyn, Poland \\ $\square$ j.heller@uwm.edu.pl
}

\section{RAFAE WARŻAEA}

University of Warmia and Mazuria in Olsztyn, Faculty of Economic Sciences, Department of Macroeconomics, Poland

$\square$ rafal.warzala@uwm.edu.pl

\begin{abstract}
Motivation: There are many victims of middle economic income trap in the world. This term commonly refers to countries that have experienced rapid growth, which enabled them to reach the status of a middle-income country, but finally have not been able to catch up the developed countries and achieve high-income status. Following this raises the question about Poland's economy position in the context of middle income trap. Aim: The aim of article is to present the position of polish economy in the context of "middle income trap theory'.

Results: Poland is a middle-income country, and some classifications say it is even a high-income country. The analysis of statistical indicators shows that in Poland there is a problem with the quality of labor, education and competencies, often because of the outflow of talented human capital. Moreover, as is known from the data prepared for the Strategy Europe 2020, Poland has the highest percentage of fixed term contracts in Europe and high poverty at work. Also the low share of the R\&D expenditure in the GDP goes together with low sub-indexes of the Global Competitiveness Index and the Index of Economic Freedom. As to the export structure, there was considerable increase in middle and upper technology goods share over the last 20 years.
\end{abstract}

Keywords: economic growth; middle income trap JEL: C33; O40; O54 


\section{Introduction}

During the last year in Poland the term 'middle income trap' has entered into common parlance and received much attention, especially in non-scientific debates. The essence of middle income trap term (MIT) in economic development commonly refers to countries that have experienced rapid growth, which enabled them to reach the status of a middle-income country, but have not been able to finally catch up to the developed countries and achieve high-income status.

The most known examples of MIT victims are some of the Latin America countries that reached status of middle development countries and after that their growth rate rapidly slow down. As an economic term, the MIT is a relatively new phenomenon and was first mentioned in 2007 in the World Bank report (Gill \& Kharas, 2007, pp. 17-18). Some of the authors indicates the approximate amount of GDP per capita, beyond which GDP growth rate often slow down, and countries fall into the middle income trap (Eichengreen et al., 2012 , p. 46). Other researches formulates an econometric test procedure confirming country's in MIT falling (Ye \& Robertson, 2016, p. 178).

The aim of this paper is to define the MIT term and to assess the extent to which Poland's economy is at risk of the occurrence of this phenomenon.

\section{Literature review}

There are many different ideas about what the MIT is. According to Gill and Kharas (2015), we can divide all MIT definitions in two group. The first group is called 'theoretical definitions' and embraces mainly primary definitions. Common framework of them is treating the MIT phenomenon as a result of government institutional and structural reforms failure. For instance, Garrett (2004, pp. 93-94) argues that middle-income countries have to 'find ways to 'tech up' and enter the global knowledge economy, so as to escape the trap of having to dumb down to compete in standardized manufacturing'. In similar way Gill and Kharas (2007, p. 5) characterize MIT countries as being 'squeezed between the low-wage poor country competitors that dominate in mature industries and the rich-country innovators that dominate in industries undergoing rapid technological change'. In turn Kharas and Kohli (2011, p. 282) claims, that countries are caught in the MIT if they 'cannot make a timely transition from resource-driven growth, with low-cost labour and capital, to productivity-driven growth'.

All definitions mentioned above are very ambiguous and give unclear interpretation of countries position in the aspect of being in middle income trap. Therefore, I focus on the second group of definitions i.e. empirical definitions. In comparison to the previous group they present a more precise definition of the term MIT. As regards term 'middle income' many authors refer it to country classification of the World Bank (Agenor, 2016, p. 773). This classification distinguishes between four income categories based on the real per capita gross 
national income (GNI) calculated on the basis of the Atlas method (World Bank, 2016a). The appropriate critical thresholds are given in table 1.

Regarding to term 'trap', it is defined in the growth literature and particularly emphasize the following main characteristics (Im \& Rosenblatt, 2013, p. 4):

- a self-perpetuating or self-reinforcing mechanism;

- difficulty breaking out of it;

- its persisting character ('stable steady state').

The last condition - persisting character is perceived differently by authors. For instance, Woo et al. (2012) states, that mentioned above period is longer than 50 years. In turn Felipe et al. (2012, p. 6), believes that the period is longer than 42 years, out of which, 14 years in the lower-middle-income range and 28 years in the upper-middle-income range.

Some researchers define MIT critical thresholds in relation to the per capita income of the US or another developed country ${ }^{1}$. Also the World Bank (2016b) suggest the relative thresholds for measuring countries position in context of middle income trap.

Taking into account above definitions it can be concluded, that there are significant differences in the thresholds within the group of absolute definitions and within the group of relative definitions. These differences lead to great variations in the empirical results (Glawe \& Wagner, 2016, p. 9).

The researches concerning the middle income trap sources focuses on several factors, that may cause that phenomenon. Among others one of the most common is concept regarding the slowdown in total factor productivity. This indicator reflects changes in productivity of technical and management progress. Mentioned downturn in total factor productivity is explained by inability to further labour force allocation from agriculture to industry (Eichengreen et al., 2012, p. 48). As regards progress in industry productivity, when based on technology import, possibilities connected with that factor are also limited.

It is also impossible continuation of the growth policy based on the export promotion supported by the undervaluation of national currency. Likewise, it is not possible to increase efficiency on the basis of investments not related to innovativeness and creating new technologies (Dingemans, 2016, p. 650). Many countries that have fallen into middle income trap, were characterized by very high investment ratio. Also important is the structure of the economy and its competitive advantage in international trade. Entry the trap of the middle income is conducive to specialization in production and sale of goods less technologically advanced (Ciesielska \& Radło, 2014, p. 5).

In turn, the factors which promote the output of this trap, are all of these features economy, which cause it can develop more innovative and modern sectors of the economy. These factors include educational structure of the popu-

${ }^{1}$ For example, Woo et al. (2012) define the middle-income range between 20\% and 55\% of the US per capita income. Alternatively, Ye \& Robertson (2016) argue that a country is in the middle-income range when its per capita income is $8-38 \%$ relative to the US's. 
lation, including a larger share of people with secondary education and lower part of population less educated. As a result, Eichengreen et al. (2012, p. 48) put the thesis, that the trap of average income can fall into these economies, that were developing relatively fast, and specialized in medium and low technology development. These developments led initially to acceleration of economic growth, but with the increase in GDP and wages, conducting this activity in these countries has become less and less profitable. Moreover, economies didn't develop any new activities based on knowledge and innovation. As a result, they have not been able to exceed the middle level of development.

A slightly different research perspective proposed (Felipe et al., 2012, p. 31). They indicated that the middle income trap should be interpreted in the context of evolutionary approach to the analysis of economic development, in which this development is a consequence of learning how to produce and export more high-tech goods. They point out, that economy development relies not on continuous improvement of the same goods production, but on acquiring the skills to shift activity towards new activities related to higher technology levels of productivity. The authors indicate a number of specific factors determining this ability.

Ability to shift production factors into high-tech production requires at the level of whole economy accumulation of human and physical capital, as well as the creation of effective law and institutional system. In turn at company level these include specific know-how and activities of all employees as well as organizational skills. As a result, countries with more diverse economies and linked industries are capable of achieving sustainable long-term growth, and, according to Felipe et al. (2012, p. 34), they are also more resistant to middle income trap falling.

For moving economy towards higher level of development, its crucial for country to have the ability for shifting production factors towards more profitable business. Countries capable of such structural changes are also able to achieve higher levels of work productivity and maintain higher level of wages. For these reasons countries that characterize diversified structure of the economy measured by variety of export products, are also more resistant to entry into the middle income trap.

Some kind of another approach to analysing factors influencing economy vulnerability to enter into middle income trap, presented Aiyar et al. (2013, p. 13). They focused on institutional conditions investigations, as well as the economy structure. For factors favouring the entrance economies into the MIT, they identified the poor quality of law, problems with enforcement contracts and property rights, as well as excessive share of the public sector and over-regulated markets. Similar to previous researches, they acknowledged, that countries, that have fallen into MIT, characterized by low share of high-tech products exported. Apart from this factor that pushed many economies into MIT was in their opinion - the worsening demographic structure (i.e. aging society). 
Another mechanism is the difficulty faced by countries whose manufacturing sector is dominated by foreign-owned firms and dependent on technology imports in transitioning to one controlled by local managers and with substantial local technology development. Multinational corporations tend not to act as conduits for technology diffusion to local firms. They generally refer to use in-house production or imports from their own suppliers, source only simple content from local firms, and repatriate profits. They locate their R\&D departments not in foreign locations but close to the marketing departments, generally at headquarters (Wade, 2016, p. 474).

\section{Methods}

To answer the question about Poland's position in the context of MIT, two methods were employed. The first is the research of middle income trap on a symmetrical analysis of growth accelerations followed by Hausmann et al. (2007). According to them if the country is in MIT, what denotes a growth slowdown of GDP growth rate, mentioned indicator must satisfy three conditions:

- $g_{\mathrm{t}, \mathrm{t}-\mathrm{n}} \geq 0.035$

- $g_{t, t+n}-g_{t, t-n} \geq 0.02$

- $y_{\mathrm{t}}>10000$ USD.

where $y_{t}$ is per capita gross domestic product (GDP) in constant 2005 international (purchasing power parity prices PPP), and $g_{t, t+n}$ and $g_{t, t-n}$ are the average growth rate between year $t$ and $t+n$ and the average growth rate between $t-n$ and $t$, respectively. Following Hausmann et al. (2007), I set $n=7$. The first condition requires that the 7 -year average growth rate of per capita GDP is 3.5\% or greater prior to the slowdown (earlier growth was fast). The second one identifies a growth slowdown with a decline in the 7-year average growth rate of per capita GDP by at least by $2 \mathrm{pp}$ (the slowdown is non-negligible). The third condition limits slowdowns to cases in which per capita GDP is greater than 10000 USD in PPP prices.

The second approach to MIT measurement is studying four characteristics of the products exported by countries. Specifically, I look at the following four indicators of structural transformation (Felipe et al., 2012, p. 35):

- diversification: the number of products that a country exports with revealed comparative advantage (RCA), i.e. $\mathrm{RCA} \geq 1$;

- diversification_core: the number of products in the metals, machinery, and chemicals categories (referred to as 'core' products) that a country exports with RCA;

- share_core: ratio of the number of 'core' products that a country exports with $\mathrm{RCA} \geq 1$ to total diversification (i.e., diversification_core/diversification);

- the index of sophistication of the export basket. This is defined as the weighted average of the level of sophistication of all the products that a country exports (Hausmann et al., 2007, p. 12). 


\section{Results}

Answering the question about position of polish economy in the context of middle income trap falling, the GDP per capita and its growth rate must be investigated. According to World Bank data Polish GDP per capita in PPP in 2009 amounted 20952 USD and increased to 26036 USD in 2016, what lets classifying our economy as high income (World Bank, 2017). As to GDP growth rate, it is illustrated on chart 1 .

According to data illustrated on chart 1, Poland average annual GDP growth rate over the 17 years was about 3.6\%, while in the EU-28 not exceed 1.5\%. Only in 2001 the score of GDP dynamic was higher in EU-28, in comparison to Poland. Moreover, during last world economic crisis, which took place in 2007-2013 period, polish economy didn't decline in any year, while in the EU negative GDP growth rate was noted in 2009 and 2012. The 2004-2009 average GDP growth rate was 4.7\% and the 2009-2016 average amounted 3.1\%. These scores can be treated as not fulfilling conditions given by Hausmann et al. (2007) to fall into middle income trap.

As Eurostat (2017) figures show, in years 2000-2016 Poland succeeded significantly to improve labour productivity indicators. Labour productivity calculated per employee increased from 56.5\% of the EU average in 2000 to $75.0 \%$ in 2016. Similarly, labour productivity calculated per hour worked ranged from $45.2 \%$ in 2000 to $59.7 \%$ in 2016 . The dynamic of labour productivity referred to previous year in Poland, in comparison to EU-28 and EU-15, is presented in chart 2.

The recovery in labour productivity, done by increasing employment rate, resulting from both growth employment rate as well as increase in number of working age population. Nevertheless, degree of labour productivity in Poland, calculated per work hour, which reflects the level of technological progress and quality of invested capital, is still just little more than half of the efficiency level in the EU. Due to relatively longer average working time per employed, Poland is succeeding in reducing the productivity gap much more than it is calculated on working time. However, because of still lower than the EU average employment rates, polish GDP per capita in 2016 was only $68 \%$ of medium GDP per capita in the European Union.

Analysing changes in employment structure, it is remarkable that in the early stages of economic development, employment flows from agriculture to productive sectors take place. When the development is continued, it is characterized by the increasing share of service sectors both in employment and value added. This phenomenon has specific effects. One of them was pointed by Baumol, who put the thesis that growing share of service sectors in developing economies results from less opportunity to replace labour force by other factors. As for the productivity of the service increases slower than in other sectors, while wages in the whole economy and sectors (either in services) grow on average in the same rate (irrespective to labour productivity), it causes service prices also 
grow. Finally, it leads to economic slowdown, because growing part of labour force is employed in less productive part of economy, i.e. services. The Baumol's disease is pointed by part of economists as crucial reason of middle income trap falling (Ciesielska \& Radło, 2014, p. 9).

Referring to structural changes in polish labour market, viewed on chart 3, it can be noted significant restructuring. In the period of 2005-2016 there was observed labour force outflow from low productivity sectors (agriculture, forestry and fishing), towards much more effective productivity sectors (information and communication, financial and insurance activities, professional, scientific and technical activities). Also favorably can be noted the employment increase in manufacturing, construction and retail trade sectors. For the contrast, the labour force inflow to administration sectors is perceived as negative trend. Such trends in labour force flows are perceived positive and enable to avoid the MIT (Cai, 2012, p. 59).

The core MIT measure is to analyze both value and trends in revealed comparative advantages (RCA) indicator, found by B. Balassa. If the country appears comparative advantage, the RCA ratio exceeds 1 . In other cases, the value is beneath 1 . The RCA value for polish SITC sectors since EU joining, are presented in tables 2 and 3.

The RCA indicators were calculated in regard to EU economy, and present position of polish competitiveness towards that countries union. In general, the RCA values are not high, but in some cases, it confirms Poland's growing comparative advantages. Two highest value of RCA concern food and other manufactured goods. In case of food, consecutive growth after entering EU can be remarked. As to other manufactured products, slight decrease in RCA value during observed period can be noted, although the value is above any others sectors. What concerns machinery and transport equipment, the RCA value has decreased, but it's value exceeds 1 yet. The rest of RCA indicators value appear less than 1. It's worth noticing fast reduction in mineral fuels RCA value - from 1.42 in 2004 to 0.61 in 2015, what is the effect of coal mines restructuration processes.

The growth of Polish exports has been more diversified in terms of sectors and destinations in recent years. While in the period 2004-2010 the machinery and transport sectors accounted for about $45 \%$ of total export growth, their contribution has decreased to $25 \%$ in the recent years. Some sectors such as agriculture-related sectors, plastic and rubber industries have, instead, increased their contribution to growth. Furthermore, Polish exporters have been more successful in accessing distant markets, especially those in the Middle East, North Africa, North America, and Latin America. Non EU and Central Asia destinations accounted for less than $10 \%$ of total exports growth in the period 2004-2006, while their contribution has increased to $20 \%$ in the period 20112013, on the back of substantial growth of non-traditional markets relative to EU growth. 
Over time, Poland has consolidated its strong comparative advantage in the wood, animal and food sectors, while it has been decreasing its export shares in the transport sector. Poland's exports in the animal, food and wood sectors notably exceed the global export share of these products. The animal sector, where Poland has a revealed comparative advantage, has slightly increased its share of exports over the period. On the other hand, the export share of the transport sector, where Poland also has a comparative advantage, has been declining over time, in particular since 2009.

Regarding presented above methods of MIT falling, 17 selected SICT subsectors appeared RCA value more than 1. Out of metal, machinery and chemical products, at least 5 were exported with RCA $>1$. What regards the third ratio, i.e. share core, in our research it equals 0.3. It means that according to Hausmann indicator, the third condition of MIT falling is fulfilled.

As to the third condition, proposed by Hausmann (Felipe et al., 2012, p. $35)$, Poland notes progressive changes in the export sophistication index, what is seen in table 4.

These results indicate that Poland had more and more sophisticated and diversified export basket during analysed period, and consequently gets into a higher income level. However, in 2015 two third of total polish export value belonged to low or medium-low technical goods. In the same time only $8.5 \%$ of total export value was classified as high-tech export (Eurostat, 2017).

An important component of restructuring the economy is an innovative activity, measured by value on research and development as percentage of GDP. As presented on chart 4, innovation of Polish economy, despite the growth recorded since 2005, is still very low. In $2015 \mathrm{R} \& \mathrm{D}$ expenditure in relation to GDP value amounted 1\%, which means they were less than a half of the average expenditure in whole European Union. Compared to countries with similar GDP per capita, Poland is behind such EU members, like Czech Republic, Slovenia, Hungary, Slovakia and even Lithuania. Moreover, dominant share of that expenditures comes from public budget, what in EU is an exception than a tendency. Polish economy has also a very low number patent application in recalculation per million inhabitants, which grew up to 16 in 2014 (the EU average is 112). These two indicators may contribute to slowdown the long term GDP growth rate and to diminish competitiveness.

\section{Conclusion}

Although Poland goes over many conditions specific for countries that catch up in middle income trap, there are some weaknesses, that may slowdown it's GDP growth rate, and delay higher income level reaching. One of them is increasing share of employed in administrative sectors. Also relative low to EU average labour activity ratio goes against European trends. What regards export competitiveness, Poland has comparative advantages rather in low or medium-low technical goods. The share of high-tech products in export value is relative low 
mainly because of very poor expenditures on $R \& D$ sector. Combined with low patent applications per million inhabitants, polish economy is treated rather a centre of European final manufacturing process, than a centre of labs and innovative processes. To change this more labour force activity must be directed towards new technologies sectors and higher share of GDP value must be provided to research and innovations.

\section{References}

Agenor, P.R. (2016). Caught in the middle? The economics of middle-income traps. Journal of Economic Surveys, 31(3). doi:10.1111/joes.12175.

Aiyar, S., Duval, R., Puy, D., Wu, Y., \& Zhang, L. (2013). Growth slowdowns and the middle-income trap. IMF Working Paper, 13(71).

Cai, F. (2012). Is there a 'middle-income trap'? Theories, experiences and relevance to China. China \& World Economy, 20(1). doi:10.1111/j.1749-124x.2012.01272.x.

Ciesielska, D.A., \& Radło, M.A. (2014). Determinanty wejścia w pułapkę średniego dochodu: perspektywa Polski. Kwartalnik Nauk o Przedsiębiorstwie, $31(2)$.

Dingemans, A. (2016). Trying to stay ahead of the curve in Chile's economic development: exploring a way out of the middle-income trap through pragmatic export development. Development Policy Review, 34(5). doi:10.1111/ dpr.12166.

Eichengreen, B., Park, D., \& Shin, K. (2012). When fast growing economies slow down: international evidence and implications for China. Asian Economic Papers, 11(1). doi:10.1162/asep_a_00118.

Eurostat. (2017). Database. Retrieved 30.03.2017 from http://ec.europa.eu/ eurostat.

Felipe, J., Abdon, A., \& Kumar, U. (2012). Tracking the middle-income trap: what is it, who is in it, and why? Levy Economics Institute Working Paper, 715.

Fortunato, P., \& Razo, C. (2014). Export sophistication, growth and the middle-income trap. In J.M. Salazar-Xirinachs, I. Nübler, \& R. Kozul-Wright (Eds.), Transforming economies: making industrial policy work for growth, jobs and development. Geneva: International Labour Office.

Garrett, G. (2004). Globalization's missing middle. Foreign Affairs, 83(6). doi:10.2307/20034139.

Gill, I., \& Kharas, H. (2007). An East Asian renaissance: ideas for economic growth. Washington: World Bank.

Gill, I., \& Kharas, H. (2015). The middle-income trap turns ten. Policy Research Working Paper, 7403. doi:10.1596/1813-9450-7403.

Glawe, L., \& Wagner, H. (2016). The middle-income trap: definitions, theories and countries concerned: a literature survey. Comparative Economic Studies, 58(4). doi:10.1057/s41294-016-0014-0. 
Hausmann, R., Hwang, J., \& Rodrik, D. (2007). What you export matters. Journal of Economic Growth, 12(1). doi:10.1007/s10887-006-9009-4.

Im, F.G., \&Rosenblatt,D. (2013). Middle-incometraps:aconceptualandempirical survey. Policy Research Working Paper, 6594. doi:10.1596/1813-9450-6594.

Kharas, H., \& Kohli, H. (2011). What is the middle income trap, why do countries fall into it, and how can it be avoided? Global Journal of Emerging Market Economies, 3(3). doi:10.1177/097491011100300302.

Wade, R.H. (2016). Industrial policy in response to the middle-income trap and the third wave of the digital revolution. Global Policy, 7(4). doi:10.1111/1758-5899.12364.

Woo, W.T., Lu M., Sachs, J.D., \& Chen, Z. (Eds.). (2012). A new economic growth engine for China: escaping the middle-income trap by not doing more of the same. Singapore: World Scientific Publishing Company, London: Imperial College Press. doi:10.1142/8598.

World Bank. (2016a). 2016 world development indicators. Retrieved 15.03.2017 from https://openknowledge.worldbank.org.

World Bank. (2016b). Poverty and shared prosperity 2016. Talking on inequity. Retrieved 16.03.2017 from https://openknowledge.worldbank.org.

World Bank. (2017). Database. Retrieved 08.04.2017 from https://openknowledge.worldbank.org.

Ye, L., \& Robertson, P.E. (2016). On the existence of a middle-income trap. Economic Record, 92(297). doi:10.1111/1475-4932.12245.

\section{Acknowledgements}

Author contributions: authors have given an approval to the final version of the article. Authors contributed to this work as follows: J.H. and R.W. developed the concept and designed the study, R.W. collected the data, R.W. analysed and interpreted the data, J.H. and R.W. prepared draft of article, J.H. and R.W. revised the article critically for important intellectual content.

Funding: this research was fully funded by the University of Warmia and Mazuria in Olsztyn, Faculty of Economic Sciences, Department of Macroeconomics statutory sources. 


\section{Appendix}

Table 1.

The GNI per capita ranges (in USD)

\begin{tabular}{ll}
\hline \multicolumn{1}{c}{ Classification } & Income range \\
\hline low-income economies & less than 1045 \\
lower-middle income economies & $1045-4125$ \\
upper-middle income economies & $4125-12736$ \\
high income economies & more than 12736 \\
\hline
\end{tabular}

Source: Own preparation based on Glawe and Wagner (2016, p. 8).

Table 2.

The RCA value for polish SITC sectors in 2004-2015 years

\begin{tabular}{lrrrrrrrrrrrr}
\hline \multicolumn{1}{c}{ Sector } & 2004 & 2005 & 2006 & 2007 & 2008 & 2009 & 2010 & 2011 & 2012 & 2013 & 2014 & 2015 \\
\hline SITC 0-1 & 0.90 & 1.08 & 1.13 & 1.13 & 1.11 & 1.08 & 1.09 & 1.11 & 1.20 & 1.23 & 1.23 & 1.24 \\
SITC 2-4 & 0.91 & 0.83 & 0.85 & 0.84 & 0.78 & 0.71 & 0.74 & 0.69 & 0.70 & 0.79 & 0.79 & 0.78 \\
SITC 3 & 1.42 & 1.04 & 0.80 & 0.75 & 0.61 & 0.55 & 0.66 & 0.66 & 0.60 & 0.58 & 0.57 & 0.61 \\
SITC 5 & 0.37 & 0.38 & 0.43 & 0.43 & 0.47 & 0.41 & 0.47 & 0.52 & 0.52 & 0.54 & 0.54 & 0.52 \\
SITC 6-8 & 1.40 & 1.36 & 1.32 & 1.28 & 1.27 & 1.21 & 1.25 & 1.29 & 1.34 & 1.33 & 1.32 & 1.33 \\
SITC 7 & 0.98 & 1.00 & 1.03 & 1.07 & 1.12 & 1.23 & 1.17 & 1.11 & 1.07 & 1.06 & 1.05 & 1.01 \\
SITC 9 & 0.01 & 0.02 & 0.03 & 0.03 & 0.03 & 0.02 & 0.02 & 0.15 & 0.34 & 0.17 & 0.08 & 0.09 \\
\hline
\end{tabular}

Note:

SITC 0-1 - food, drinks and tobacco

SITC $2-4$ - raw materials

SITC 3 - mineral fuels, lubricants and related materials

SITC 5 - chemicals and related products

SITC 6-8 - other manufactured goods

SITC 7 - machinery and transport equipment

SITC 9 - commodities and transactions not classified

Source: Own preparation based on Eurostat (2017). 
Table 3.

The RCA value for polish selected SITC subsectors in 2004-2016 years

\begin{tabular}{lccccccccccccc}
\hline SITC group & 2004 & 2005 & 2006 & 2007 & 2008 & 2009 & 2010 & 2011 & 2012 & 2013 & 2014 & 2015 & 2016 \\
\hline 0 & 2.73 & 2.69 & 2.38 & 2.16 & 1.87 & 2.22 & 2.33 & 2.32 & 2.52 & 2.29 & 2.31 & 2.21 & 2.18 \\
2 & 0.95 & 0.80 & 0.58 & 0.55 & 0.66 & 0.62 & 0.70 & 0.76 & 0.87 & 0.98 & 1.10 & 1.08 & 1.17 \\
53 & 1.16 & 1.26 & 1.28 & 1.46 & 1.41 & 1.37 & 1.35 & 1.36 & 1.37 & 1.43 & 1.45 & 1.32 & 1.28 \\
55 & 2.04 & 1.88 & 1.72 & 1.89 & 2.16 & 2.60 & 2.49 & 2.13 & 2.10 & 1.82 & 1.78 & 1.79 & 1.86 \\
56 & 4.67 & 3.98 & 2.75 & 2.44 & 3.20 & 1.56 & 1.95 & 2.25 & 1.98 & 2.17 & 1.81 & 1.91 & 1.54 \\
58 & 2.14 & 2.41 & 2.40 & 2.36 & 2.30 & 1.91 & 1.74 & 1.75 & 1.80 & 1.86 & 1.78 & 1.73 & 1.74 \\
6 & 1.75 & 1.70 & 1.73 & 1.72 & 1.64 & 1.69 & 1.62 & 1.58 & 1.56 & 1.53 & 1.54 & 1.57 & 1.60 \\
61 & 0.36 & 0.49 & 0.54 & 0.66 & 0.57 & 0.32 & 0.41 & 0.68 & 0.80 & 0.78 & 0.92 & 1.27 & 1.44 \\
62 & 2.32 & 2.33 & 2.35 & 2.56 & 2.20 & 2.26 & 2.34 & 2.41 & 2.26 & 2.05 & 2.02 & 2.12 & 2.31 \\
63 & 4.52 & 4.35 & 3.86 & 3.78 & 3.48 & 2.95 & 3.11 & 2.95 & 2.84 & 2.58 & 2.64 & 2.38 & 2.28 \\
64 & 2.32 & 2.54 & 2.38 & 2.49 & 2.48 & 2.61 & 2.47 & 2.49 & 2.63 & 2.60 & 2.55 & 2.42 & 2.40 \\
65 & 0.85 & 0.99 & 1.01 & 1.03 & 0.92 & 0.98 & 0.95 & 0.93 & 1.00 & 0.99 & 1.01 & 1.09 & 1.15 \\
68 & 2.52 & 2.18 & 1.98 & 1.73 & 1.73 & 2.28 & 2.25 & 2.40 & 1.65 & 1.95 & 2.07 & 2.32 & 2.21 \\
69 & 1.94 & 2.24 & 2.56 & 2.72 & 2.41 & 2.29 & 2.10 & 2.14 & 2.32 & 2.18 & 2.15 & 2.05 & 1.99 \\
7 & 0.82 & 0.87 & 0.92 & 0.94 & 1.01 & 0.99 & 1.00 & 1.03 & 1.02 & 1.08 & 1.04 & 1.07 & 1.01 \\
71 & 0.77 & 0.82 & 0.92 & 0.85 & 0.93 & 1.03 & 1.17 & 1.09 & 1.11 & 1.23 & 1.28 & 1.43 & 1.46 \\
79 & 2.16 & 2.21 & 2.29 & 2.06 & 1.73 & 2.29 & 2.06 & 2.63 & 1.97 & 2.53 & 2.33 & 2.36 & 1.68 \\
\hline
\end{tabular}

Note:

0 - food and live animals

2 - crude materials, inedible, except fuels

53 - dyeing, tanning and coloring materials

55 - essential oils and resinoids and perfume materials

56 - fertilizers

58 - plastic in non-primary forms

6 - manufactured goods classified chiefly by material

61 - leather, leather manufactures

62 - rubber manufactures

63 - cork and wood manufactures

64 - paper, paperboard and articles of paper pulp

65 - textile yarn, fabrics, made-up articles

68 - non-ferrous metals

69 - manufactures of metals

7 - machinery and transport equipment

71 - power generating machinery and equipment

79 - other transport equipment

Source: Own preparation based on Eurostat (2017). 
Table 4.

Export sophistication index for Poland selected years

$\begin{array}{ccccccccc}2000 & 2002 & 2004 & 2006 & 2008 & 2010 & 2012 & 2014 & 2016 \\ 71.67 & 70.36 & 68.95 & 68.76 & 72.88 & 72.63 & 71.79 & 72.36 & 72.79\end{array}$

Source: Own preparation based on Fortunato \& Razo (2014, p. 286) and Eurostat (2017).

Chart 1.

Poland and EU-28 annual GDP growth rate in 2000-2016 years (in \%)

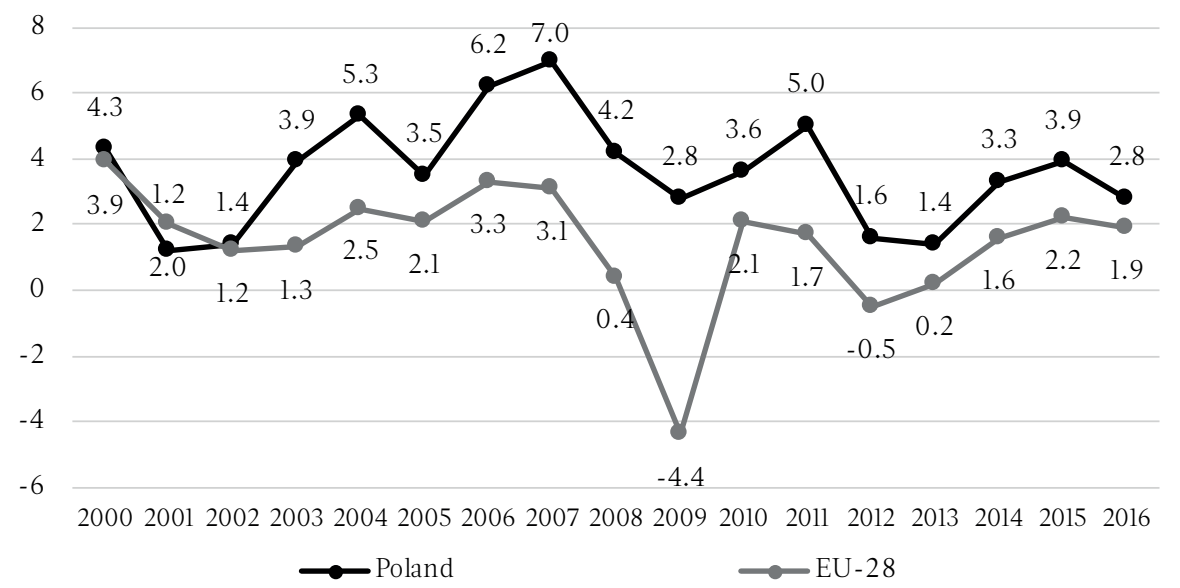

Source: Own preparation based on Eurostat (2017).

Chart 2.

Labour productivity dynamics in Poland and EU countries (in \%)

8

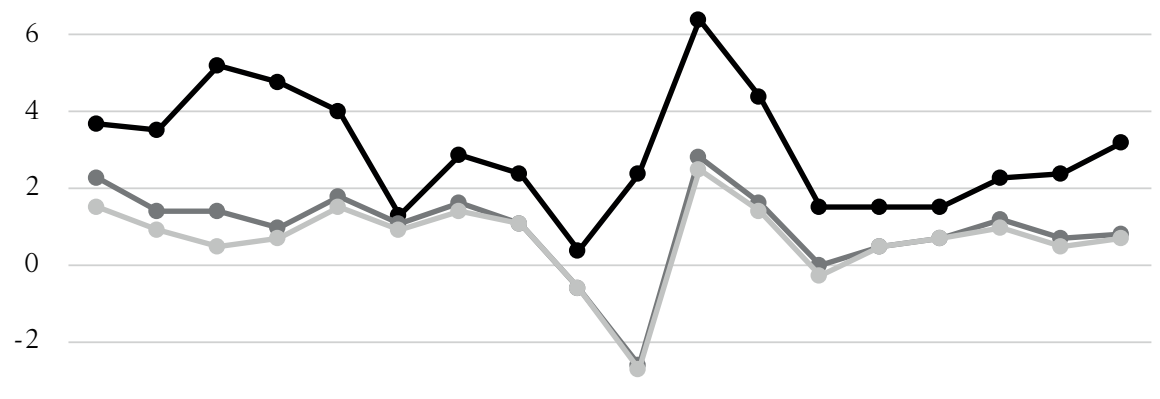

$-4$

200020012002200320042005200620072008200920102011201220132014201520162017

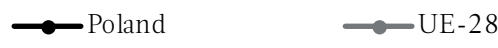

UE-15

Source: Own preparation based on Eurostat (2017). 


\section{Chart 3.}

Changes in the number of employees in relation to labour productivity in polish economic sectors during period of 2005-2016

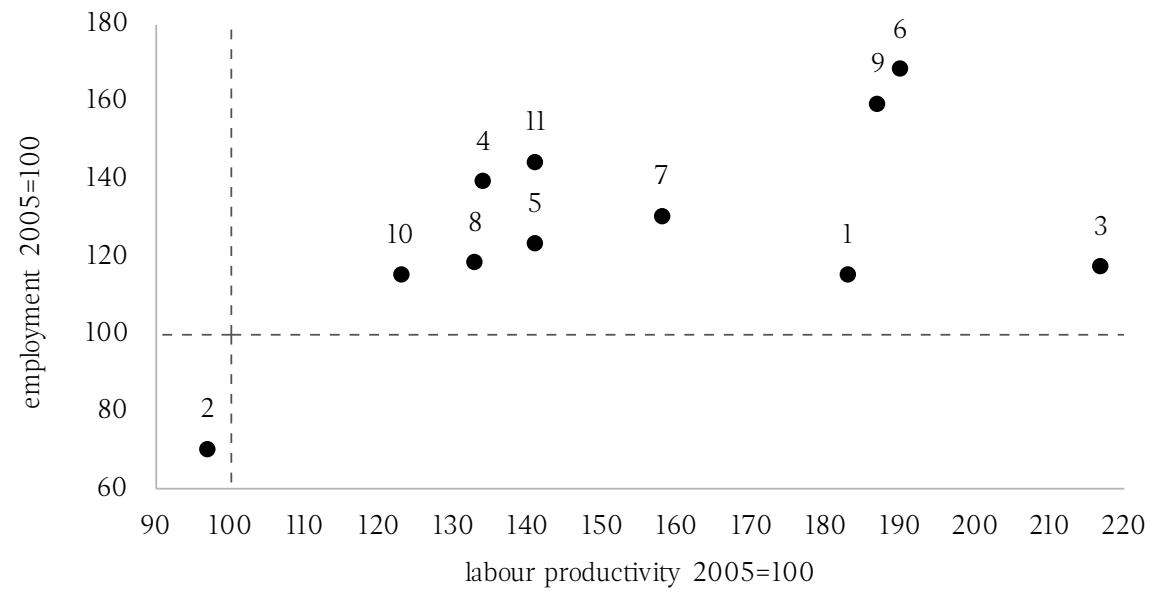

Note:

1 - industry (except construction)

2 - agriculture, forestry and fishing

3 - manufacturing

4 - construction

5 - wholesale and retail trade, transport

6 - information and communication

7 - financial and insurance activity

8 - real estate activities

9 - professional, scientific and technical

10 - public administration, defence, education

11 - arts, entertainment and recreation

Source: Own preparation based on Eurostat (2017). 
Chart 4.

Research and development expenditure (in \% of GDP)

3.0

2.5

2.0

1.5

1.0

0.5

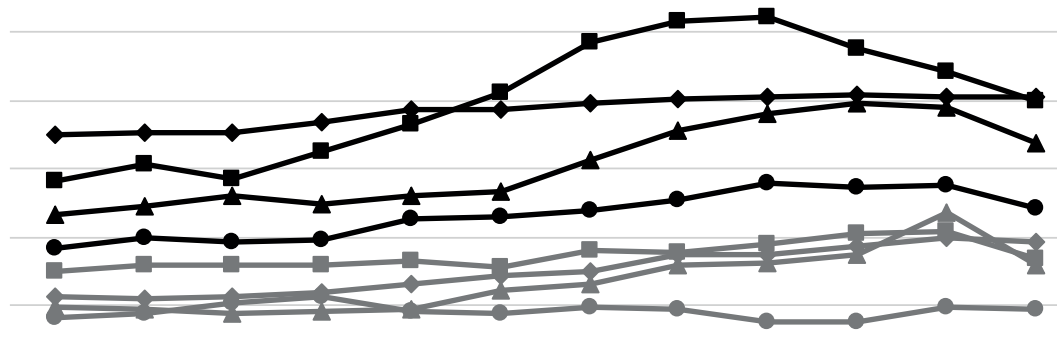

0.0

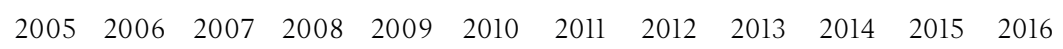

$\underset{\sim}{\mathrm{EU}-28}$

$\underset{\longrightarrow \text { Poland }}{\longrightarrow \text { Lithuania }}$

$\longrightarrow$ Czechia

$\longrightarrow$ Slovakia

Source: Own preparation based on Eurostat (2017). 
